\title{
Effects of Oven Drying on the Physicochemical Composition of Eggplant (Solanum Aethiopicum L.)
}

\author{
Alice Christine EKISSI ${ }^{1 *}$, Kan Benjamin KOUAME ${ }^{1}$, Grah Avit Maxwell BEUGRE ${ }^{1}$, Séraphin KATI- \\ COULIBALY ${ }^{2}$ \\ ${ }^{1}$ Agro-valorization Laboratory, Faculty of Agroforestry, University Jean Lorougnon Guede of Daloa \\ Daloa, Côte d'Ivoire \\ 2 Laboratory of Nutrition and Pharmacology, of Biosciences, University Felix HouphouetBoigny of Cocody-Abidjan \\ Abidjan, , Côte d'Ivoire \\ ${ }^{*}$ Corresponding author's email: ekissialicec [AT] gmail.com
}

\begin{abstract}
The objective of this work is to determine the effects of oven drying on the physico-chemical composition of eggplant (Solanum Aethiopicum L.). The samples were collected in the field school of the University Jean Lorougnon Guédé in Daloa. The water contents, $\mathrm{pH}$, titratable acidity and vitamin $\mathrm{C}$ were determined at different temperatures (50 ${ }^{\circ} \mathrm{C}, 60^{\circ} \mathrm{C}, 80^{\circ} \mathrm{C}$ and $90^{\circ} \mathrm{C}$ ) and time. Analyzes show that the moisture (92 to 5\%), pH (5.67 to 3.44) and vitamin $\mathrm{C}$ (1.095 to $0.508 \mathrm{mg} E A A / 100 \mathrm{~g}$ ) contents decrease progressively as a function of the drying time and over time. as the temperature rises. However, the titratable acidity contents of eggplants increase $(0.0153$ to 0.229 meq / $100 \mathrm{~g})$ gradually with increasing temperature. Increasing temperature and time lead to a decrease in humidity, $\mathrm{pH}$ and vitamin $\mathrm{C}$ and an increase in the titratable acidity content of eggplants during drying.
\end{abstract}

Keywords--- Eggplant; Solanum Aethiopicum, drying, vitamin C

\section{INTRODUCTION}

Food crops are mainly intended for local consumption. It is made up of vegetable crops which are of prime importance for the staple diet in Côte d'Ivoire, as they are the main source of vitamins and trace elements for the populations [1]. Among these vegetable crops, eggplant (Solanum aethiopicum L.) represents an important source of vitamins and minerals essential for human nutrition, with a nutritional value comparable to that of tomatoes.

However, a major problem remains: that of post-harvest losses. According to [2] nearly 50 to $60 \%$ of fresh food is lost between harvest and consumption. These losses are due either to the perishable nature of market garden produce or to pest animals. They can cause serious shortages throughout the year as its products are seasonal. At the same time, these vegetable crops, consumed in large quantities, are not always available all year round. A large part of this agricultural production (eggplant, tomato, dates, etc.) lends itself perfectly to conservation by drying to ensure continuity in its availability [3].

To compensate for these times of shortages and loss of crops, the transformation of products in times of plenty is essential. There are several methods of processing market gardeners, each of which allows them to be preserved. However, the most important is preservation by heat treatment [4] which includes: drying, sterilization, pasteurization and canning. Drying is one of the most energy-consuming unit operations in the processing industries. In a drying process, a great deal of energy is required for the substantial change in heating and phase of the water [5]. The heat not only reduces the microbial load of the product, but also its water content, thus promoting its preservation. It is in this context that this work, which consists of studying and validating an innovative drying technique (oven) on a variety of eggplant (Solanum Aethiopicum L.), which is considered among the varieties most appreciated by the consumer, fits into this context. .

To avoid shortages and losses, it is important to process the eggplant for better preservation. Several existing processing techniques, however, each of them must be able to ensure both the safety and the nutritional and organoleptic quality of the product. Thus, the objective of this work is to evaluate the physicochemical composition of eggplant (Solanum Aethiopicum L.) during drying in a ventilated oven in order to improve shelf life effectively. 


\section{MATERIEL AND METHODS}

\subsection{Materiel}

\subsubsection{Plant material}

The plant material used (Figure 1) consists of eggplant (Solanum Aethiopicum L) which is one of the local varieties most consumed in Côte d'Ivoire.

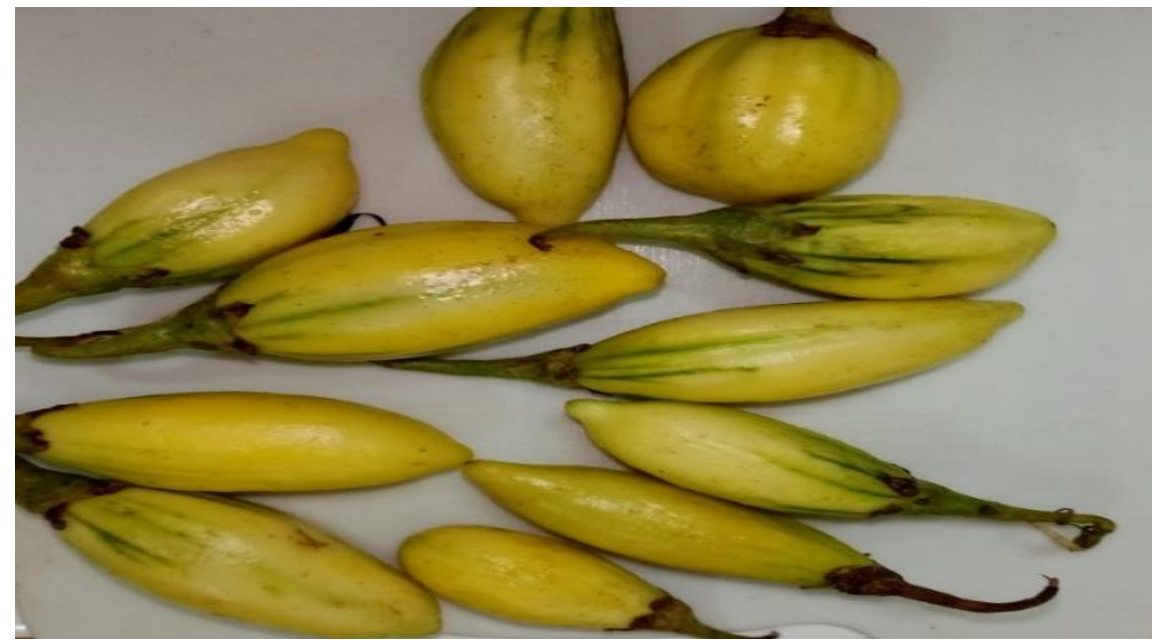

Figure 1: Photograph of eggplants (Solanum Aethiopicum L)

\subsection{Methods}

\subsubsection{Preparation and drying of plant material}

Fresh eggplants were collected from the University field school just after harvest. After their collection, they are transported in baskets lined inside with newspaper to preserve their firmness to the laboratory to ensure their drying in the oven. Eggplants intended for drying must be healthy, ripe, firm and without any injuries. Sorting therefore made it possible to remove from the batch the spoiled, unripe eggplants that had lost their firmness. The eggplant stems were removed with a knife. The eggplants were then washed well with tap water followed by distilled water, then sliced into 5 grams, 10 grams and 15 grams. These different slices have undergone drying in an oven (conventional process at different temperatures).

\subsubsection{Physicochemical analyzes}

\subsubsection{Determination of water content}

To determine the water content a moisture test was carried out by the method of [6]. In addition, the different quantities of eggplant mass $(5,10$ and 15 grams) were admitted into crucibles of known mass (m0) and were brought to the shelves of the ventilated oven at different temperatures $\left(50,60,70,80\right.$ and $90^{\circ} \mathrm{C}$ ) to a constant mass. Several (a minimum of three) tests were performed for each sample. The moisture content calculation is as follows (Equation 1):

$$
\mathrm{H} \%=\left(\mathbf{1}-\left(\mathbf{P}_{0}-\mathbf{P}_{\mathrm{s}}\right) / \mathbf{P}_{0}\right) * 100
$$

$\mathrm{H} \%$ : percentage of humidity

P0: initial weight of the sample

Ps: dry weight of the sample

\subsubsection{Determination of $\mathbf{p H}$ and titratable acidity}

The acidity and the $\mathrm{pH}$ of the non-dried and dried eggplants were determined according to the method described by [7]. The different quantities of mass have first undergone grinding and a quantity of $20 \mathrm{~g}$ of the dried eggplant powder is diluted in $200 \mathrm{~mL}$ of distilled water forming a $10 \%$ (m/v) suspension. This suspension was stirred at room temperature $\left(28^{\circ} \mathrm{C}\right)$ for 30 minutes and centrifuged at $6000 \mathrm{rpm}$ for 15 minutes.

The hydrogen potential is a global expression of the acidity of a product. Thus, the $\mathrm{pH}$ of the eggplant solutions is measured directly on the supernatant collected using a pH meter. For this purpose, while stirring the obtained solution, the electrode and the probe of the pH meter (HANNA HI-98150, USA) were immersed and the pH was read directly on the screen. Before determining the $\mathrm{pH}$ of the food, the device ( $\mathrm{pH}$ meter) was calibrated using two commercial buffer solutions $\mathrm{pH}=4$ and $\mathrm{pH}=7$. 
The purpose of titratable acidity is to approximate the total content of natural organic acids. The assay being carried out by titration with a strong base by turning a colored indicator. For this purpose, a volume of $50 \mathrm{~mL}$ of the supernatant obtained previously from the eggplants was titrated with a sodium hydroxide solution $(0.1 \mathrm{~N} \mathrm{NaOH})$ in the presence of phenolphthalein (1\% in ethanol). The concentration of acids in foods, such as

acetic, citric, lactic and malic acids, was determined by titration of several test portions (5 mL) with sodium hydroxide until the change to $\mathrm{pH} 8.1$ [8].

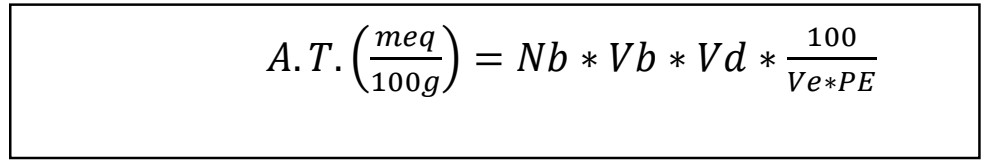

$\mathrm{Vb}$ : Volume of soda poured $(\mathrm{mL})$

$\mathrm{Nb}$ : Normal sodium hydroxide $(0.1 \mathrm{~N})$

Vd: Volume of diluent or distilled water $(\mathrm{mL})$

Ve: Test volume (mL)

PE: Test portion $(5 \mathrm{~g})$

AT: Titratable acidity

\subsubsection{Determination of vitamin C ( $L$-ascorbic acid)}

The vitamin $\mathrm{C}$ content of eggplant fruit-vegetables from the different treatments was determined by the indirect iodometric titration method described by [9]. This method consisted of placing a known volume (5 mL) of eggplant solution in the presence of a known amount of excess iodine. All vitamin $\mathrm{C}$ reacts with diodine in excess. The excess iodine is determined with a solution of sodium thiosulfate $\mathrm{Na}_{2} \mathrm{~S}_{2} \mathrm{O}_{3}$. Thus, a quantity of 10 grams of eggplant powder was crushed and dissolved in a volume of $100 \mathrm{~mL}$ of distilled water. The mixture is then filtered and the juice obtained is collected in a beaker. In a beaker with a capacity of $20 \mathrm{~mL}$, a volume of $5 \mathrm{~mL}$ of the eggplant solution comprising a few drops of starch is added to a volume of $5 \mathrm{~mL}$ of iodine of known concentration (5.10-3 mol / L). The solution is then black from the excess iodine. The excess iodine in the solution is titrated with a solution of sodium thiosulfate $\left(\mathrm{Na}_{2} \mathrm{~S}_{2} \mathrm{O}_{3}\right)$ at $5.10^{-3}$ mol / L until complete disappearance of the black color. The amount of vitamin $\mathrm{C}$ contained in the fruits was determined by the following formula:

$$
\begin{aligned}
& \qquad V c\left(\frac{m g}{100 g}\right)=(V e-v b) * N * \frac{88}{P V} \\
& \mathrm{r}=\mathrm{mg} \text { of ascorbic acid in 100g of fresh material } \\
& \mathrm{Ve}=\mathrm{ml} \text { of } \mathrm{Na} 2 \mathrm{~S} 2 \mathrm{O} 3 \text { used to titrate the extract } \\
& \mathrm{Vb}:=\mathrm{ml} \text { of used for the blank (control) } \\
& \mathrm{N}:=\text { normality of } \mathrm{Na} 2 \mathrm{~S} 2 \mathrm{O} 3(0.001 \mathrm{~N}) \\
& 88:=\text { Milliequivalent weight of ascorbic acid } \\
& \mathrm{P}=\text { weight of the fresh crushed material (gr) } \\
& \mathrm{V}=\text { volume of the title extract. }
\end{aligned}
$$

\subsubsection{Statistical analyzes of data}

The data collected from the physicochemical characterization of the eggplant samples were subjected to statistical analysis. This analysis was performed using STATISTICA 7.1 software at a 5\% level $(\mathrm{p}<0.05)$. The results are presented as the mean \pm standard deviation. Analysis of variance (ANOVA) was performed to compare the levels of physicochemical parameters in the different samples 


\subsection{Results}

\section{RESULTS AND DISCUSSION}

\subsubsection{Drying kinetics}

The results of the change in the humidity of the different slices of eggplant dried in a ventilated oven at different temperatures are shown in Figures 6a-e. The drying kinetics of eggplants have the same pace for the different temperatures. In fact, eggplants have an initial water content of around $92 \mathrm{~g} / 100 \mathrm{~g}$. The sample is dried to its constant mass. It can be seen that the more the temperature increases, the more the drying time decreases. The water losses gradually increase with the drying time. Moreover, the drying kinetics of eggplants at $5 \mathrm{~g}$ and $10 \mathrm{~g}$ are a little different from that obtained for eggplants of $15 \mathrm{~g}$. Two phases have been noted in the figures: a phase of dramatic water loss (phase 1) which corresponds to the start of the drying process and a phase corresponds to the slowing down of water loss for the products (phase 2).

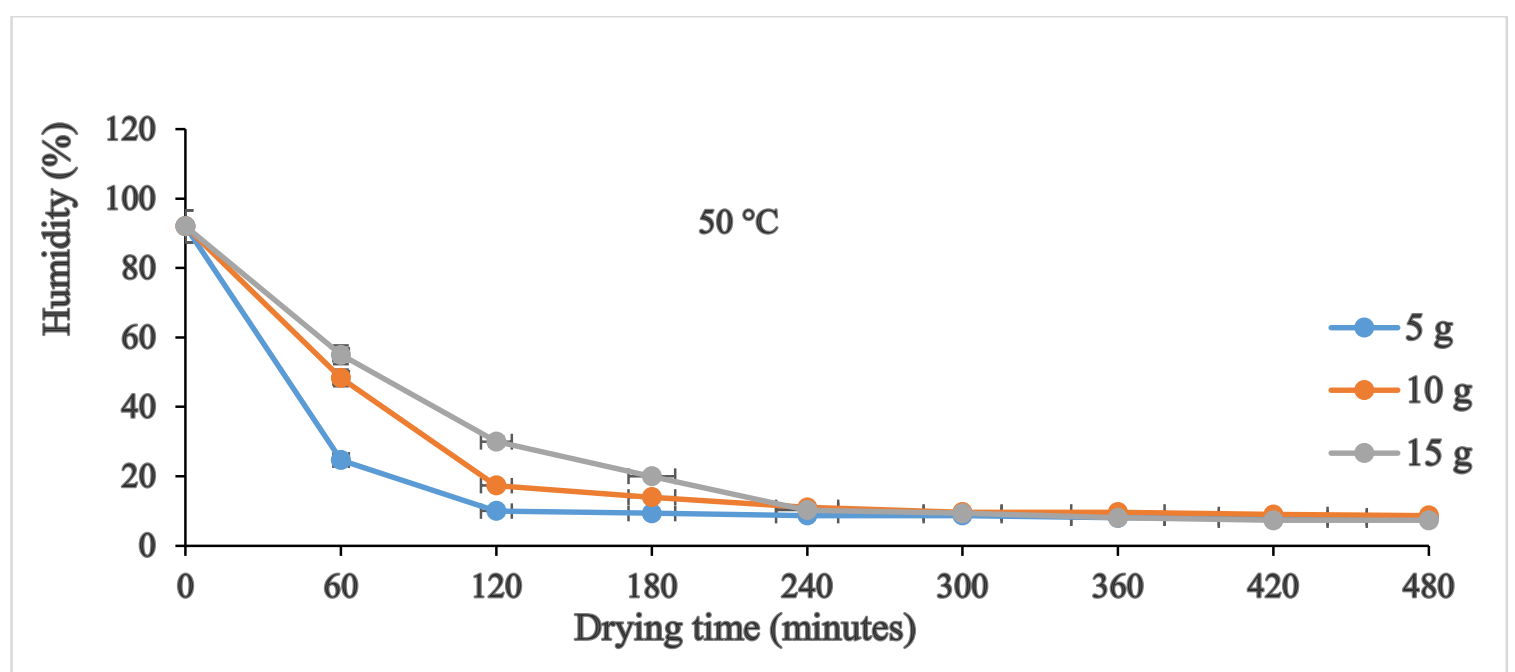

Figure 6a: Evolution of the humidity of the different proportions of eggplant dried in a ventilated oven at a temperature of $50^{\circ} \mathrm{C}$

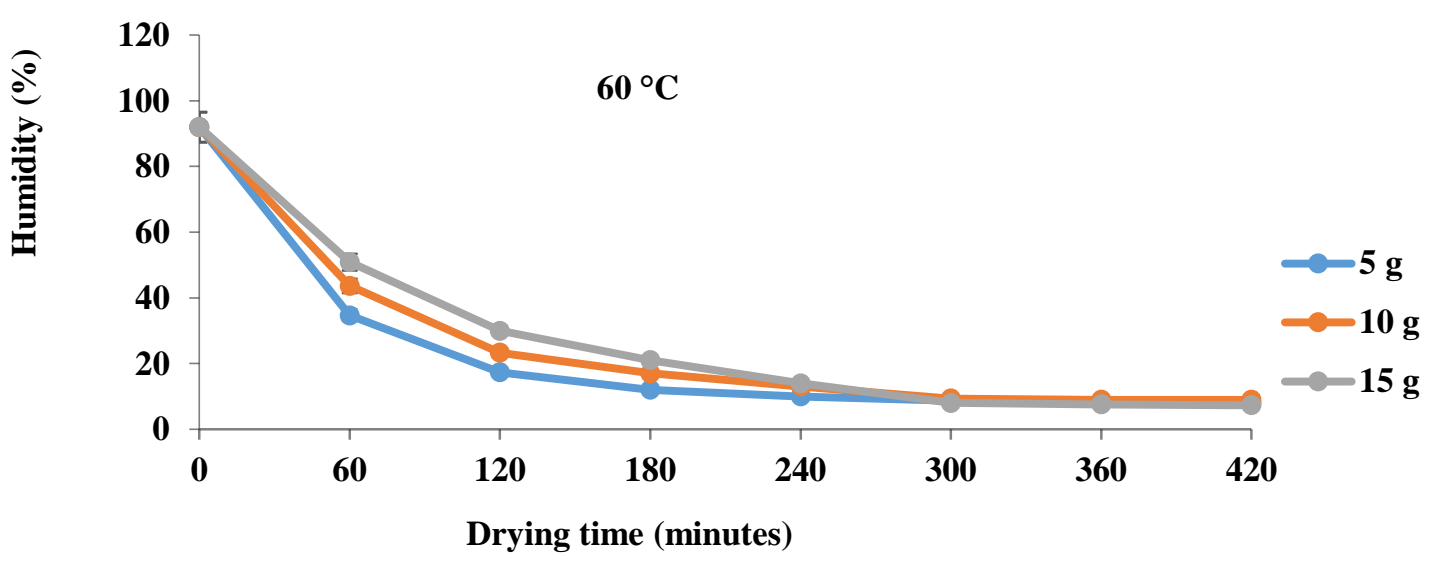

Figure $6 \mathbf{b}$ : Evolution of the humidity of the different proportions of eggplant dried in a ventilated oven at a temperature of $60^{\circ} \mathrm{C}$ 


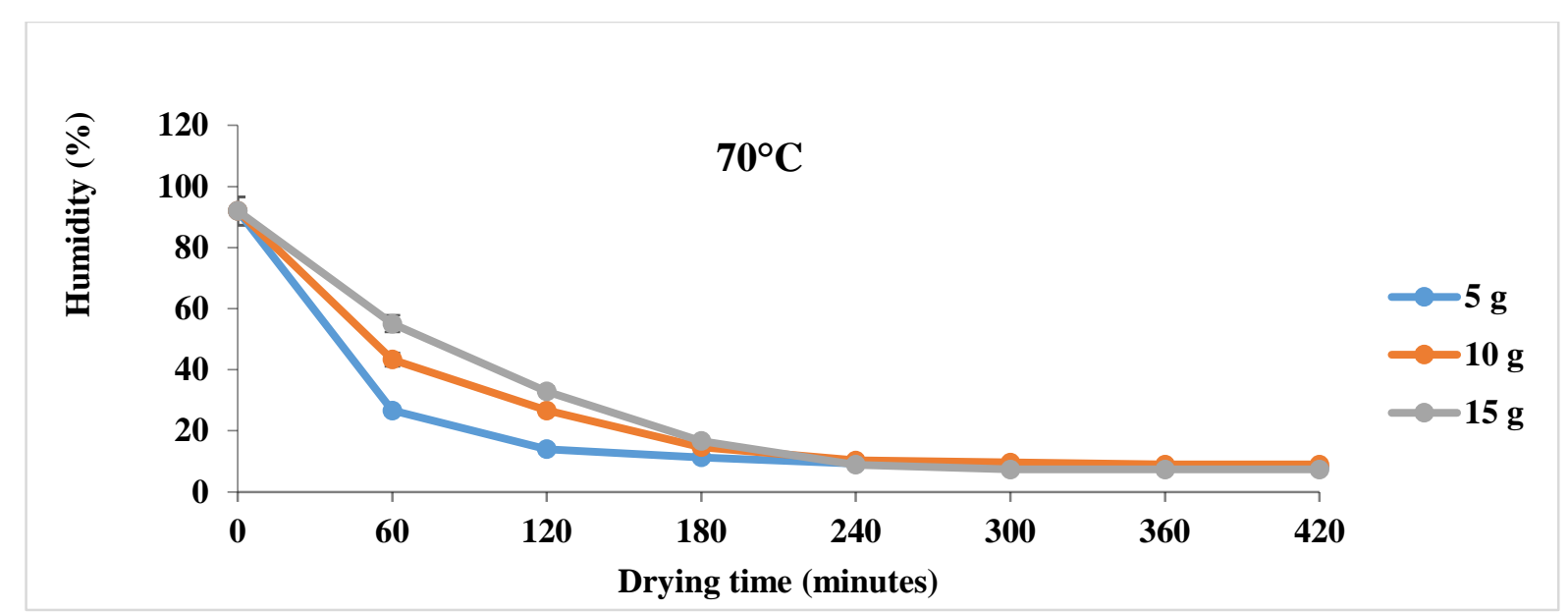

Figure $\mathbf{6 c}$ : Evolution of the humidity of the different proportions of eggplant dried in a ventilated oven at a temperature of $70^{\circ} \mathrm{C}$.

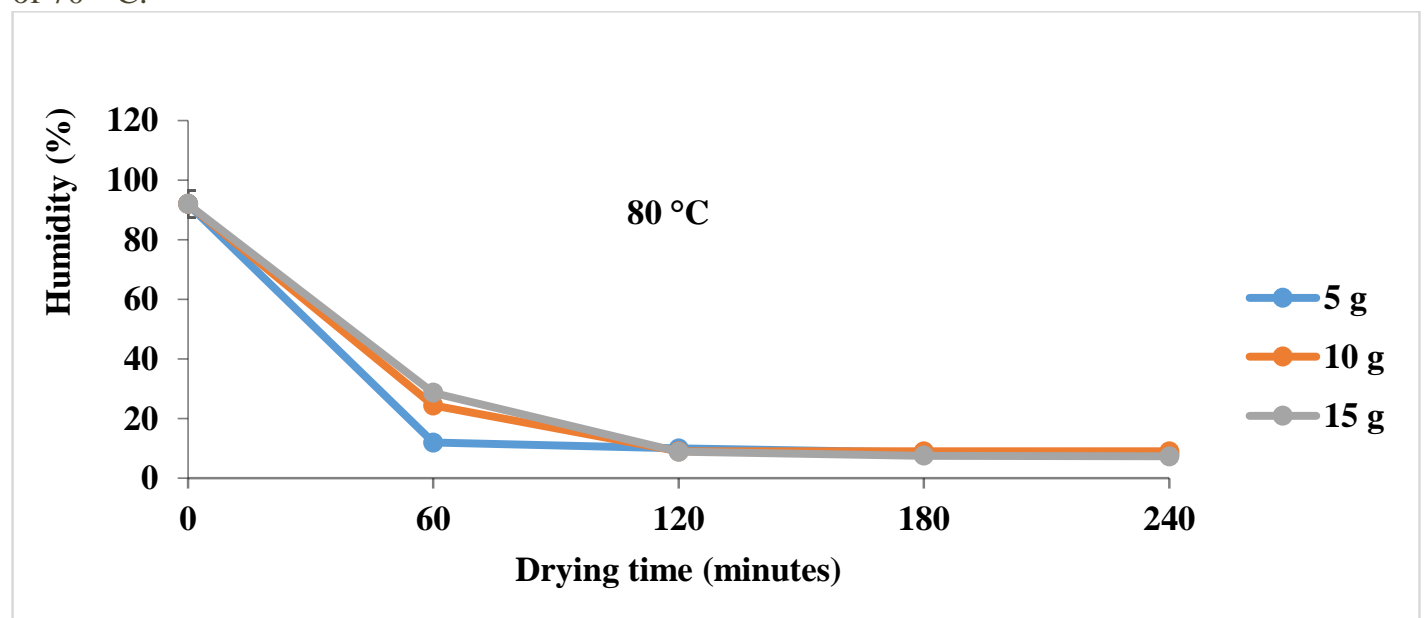

Figure 6d : Evolution of the humidity of the different proportions of eggplant dried in a ventilated oven at a temperature of $80{ }^{\circ} \mathrm{C}$

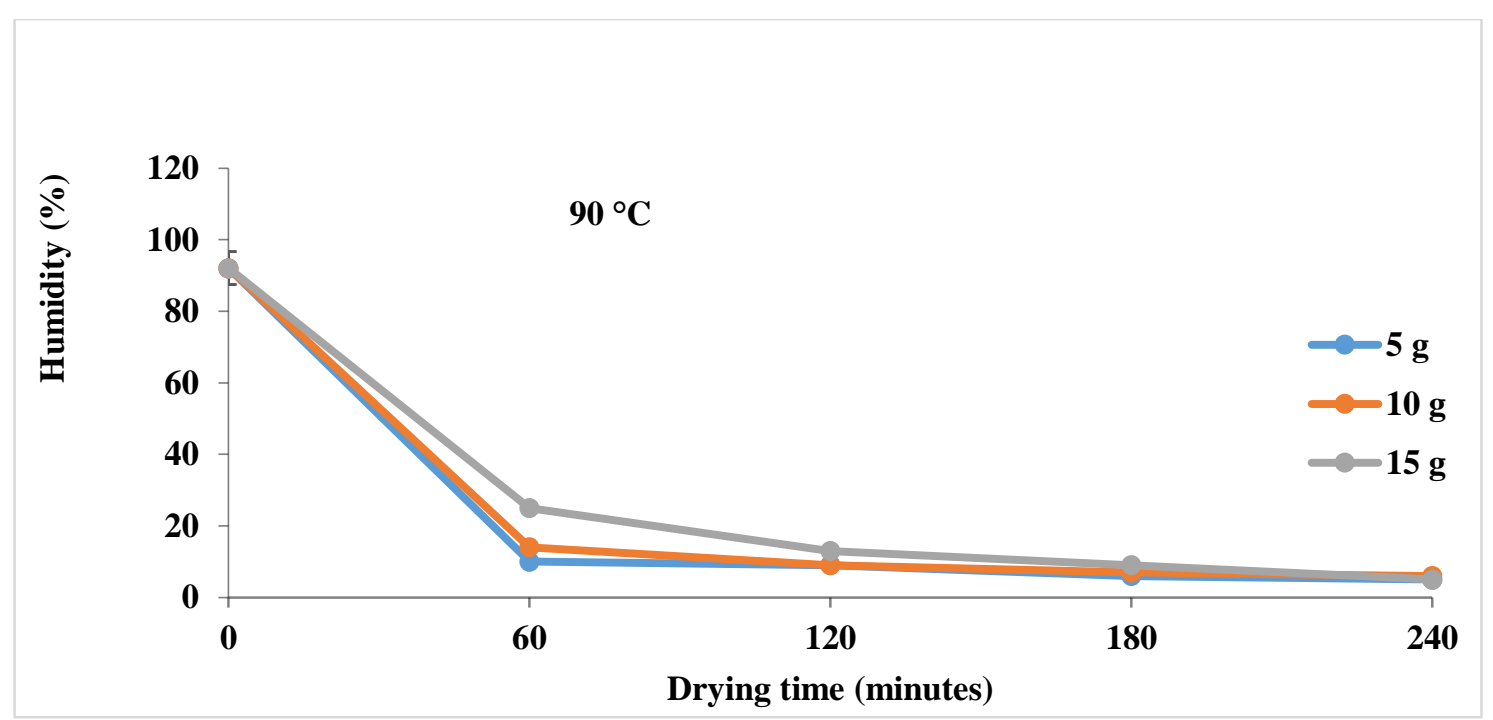

Figure 6e : Evolution of the humidity of the different proportions of eggplant dried in a ventilated oven at a temperature of $90{ }^{\circ} \mathrm{C}$

\subsection{2. pH}

The $\mathrm{pH}$ of the eggplant samples studied remained statistically the same (Figure 7). However, this pH is between (5.50 and 6.00). The results obtained show that the $\mathrm{pH}$ decreases with increasing drying temperature. The statistical study shows 
the existence of a significant difference $(\mathrm{p} \leq 0.05)$ in the loss of hydrogen potential for the different temperatures. In fact, the losses in hydrogen potential are faster for temperatures of $80^{\circ} \mathrm{C}$ and $90^{\circ} \mathrm{C}$.

The results of this study also show that the rate of $\mathrm{pH}$ loss, for a given mass, changes succinctly from one temperature to another. The statistical study revealed the existence of a significant difference $(\mathrm{p} \leq 0.05)$ in the rate of loss in $\mathrm{pH}$ with the evolution of drying temperature, for a given slice mass. Indeed, the fastest rate of loss is recorded with $5 \mathrm{~g}$ eggplant slices dried at a temperature of $80^{\circ} \mathrm{C}$ and $90^{\circ} \mathrm{C}$.

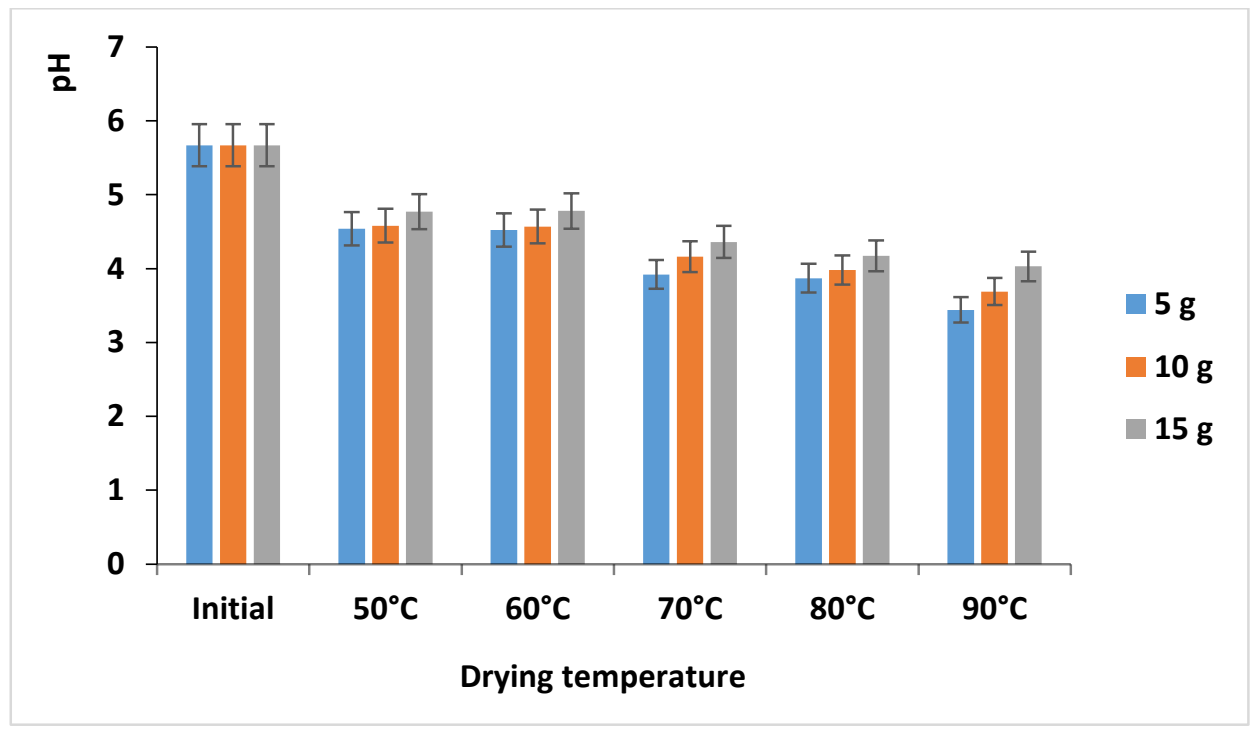

Figure $7: \mathrm{pH}$ of eggplant extracts dried in a ventilated oven of different masses $(5,10$ and $15 \mathrm{~g})$ according to different temperatures

\subsubsection{Titratable acidity}

The results obtained show that the acidity changes with increasing drying temperature (Figure 8). The statistical study revealed the existence of a significant difference $(\mathrm{p} \leq 0.05)$ in the acidity rate with the evolution of the drying temperature, for a mass of given slice. This is because the increase in acidity is faster for slices of 5, followed by 10 and then $15 \mathrm{~g}$ for the same temperature.

The results of this study also show that the acidity rate for a given mass of slices changes from one temperature to another. Indeed, the highest acidity rate is recorded by temperatures of $80^{\circ} \mathrm{C}$ and $90^{\circ} \mathrm{C}$.

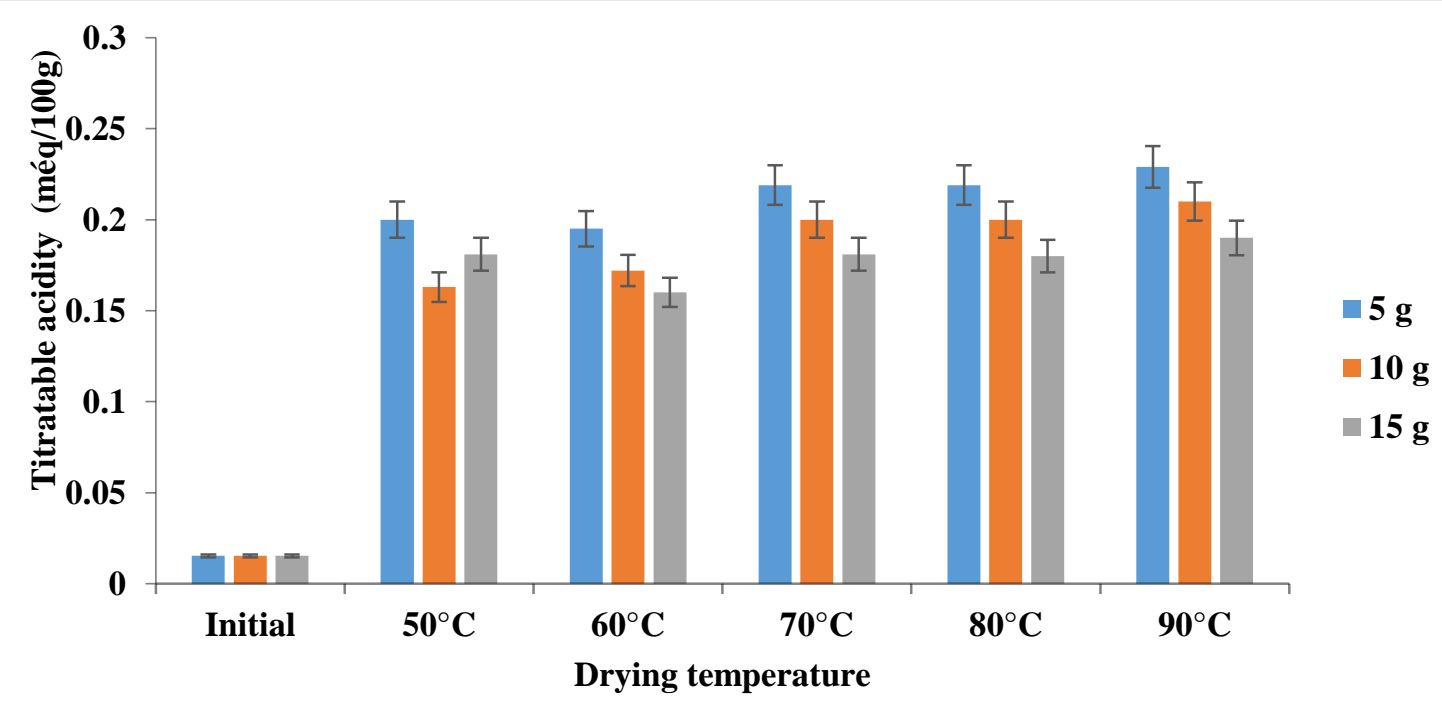

Figure 8 : Evolution of the titratable acidity of the different proportions of the dried eggplant according to the different temperatures. 


\subsubsection{Vitamin C}

The results obtained show that the vitamin $\mathrm{C}$ content changes with increasing drying temperature (Figure 9). The statistical study shows the existence of a significant difference $(\mathrm{p} \leq 0.05)$ in the loss of vitamin $\mathrm{C}$ of the slices for the same temperature. Indeed, vitamin $\mathrm{C}$ losses are faster for $5 \mathrm{~g}$ slices, followed by $10 \mathrm{~g}$ then $15 \mathrm{~g}$ for the same temperature.

The results of this study also reveal that the rate of loss of vitamin $\mathrm{C}$, for a given mass of eggplant slice, changes from one temperature to another. The fastest rate of loss is recorded with $5 \mathrm{~g}$ eggplant slices dried at $50{ }^{\circ} \mathrm{C}$ and $60^{\circ} \mathrm{C}$.

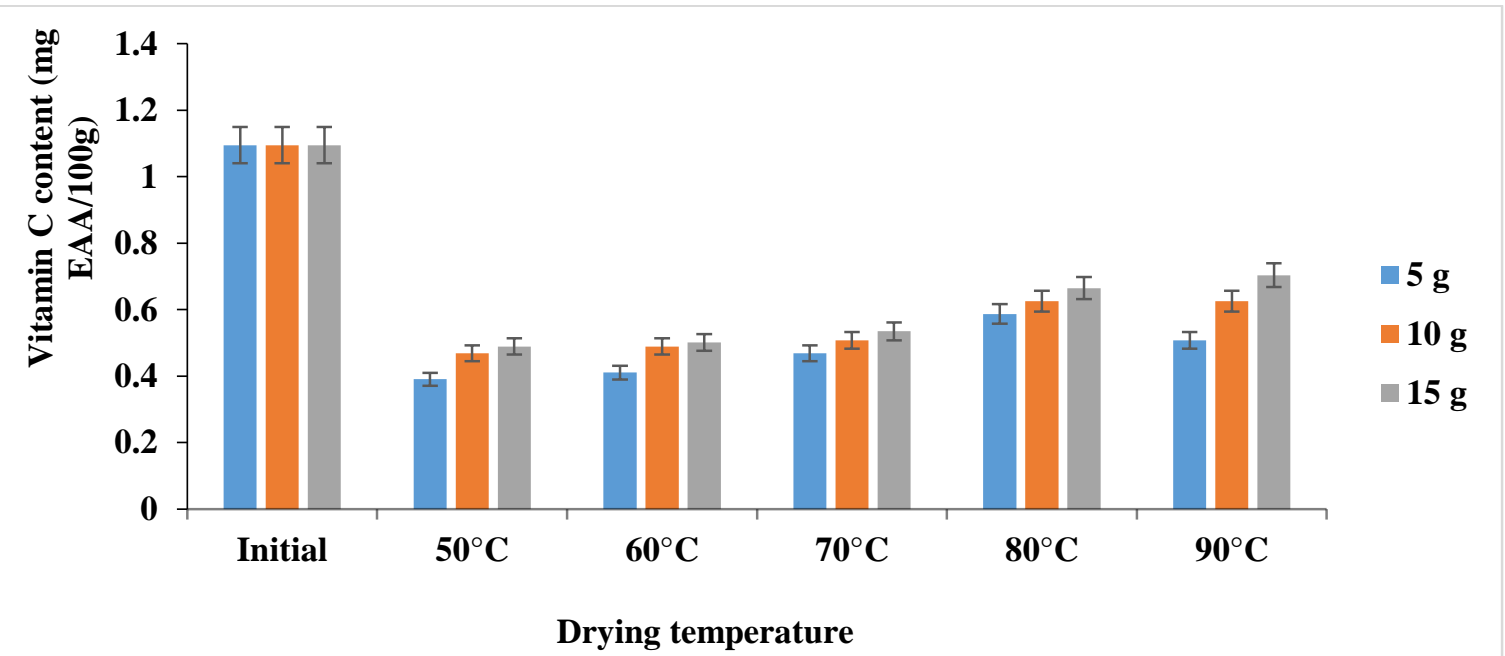

Figure 9: Vitamin C from different masses of eggplant dried in a ventilated oven $(5,10$ and $15 \mathrm{~g})$ depending on the different temperatures.

\subsection{Discussion}

Drying is one of the oldest and most widely used methods for preserving fruits, vegetables and aquatic products as it lowers water activity, prolongs shelf life [10] slows down microbial growth, enzyme activity, and chemical reaction [11]. The use of various drying methods is for better conservation of these parameters [12]. According to [2], the temperature has an influence on the evolution of the water content during drying. The influence of temperature on the drying kinetics is significant, an increase in temperature leads to a decrease in the water content. The drying time is not the same for all five temperatures; the drying time is shorter with increasing temperatures. Temperatures below $50{ }^{\circ} \mathrm{C}$ do not promote sufficient movement of water vapor from the food to achieve the desired humidity level, while temperatures above $70^{\circ} \mathrm{C}$ cause volatilization of the food. Components of the product, causing loss of quality [13]. Drying generally brings about a change in the physical and chemical state of plants [14]. Temperature, exposure time and drying method are very important parameters since they have a direct influence on water loss and weight reduction of plant products. They also have significant effects on mineral losses and firmness reductions in [15]. Increasing the drying temperature of eggplants accelerates their dehydration and decreases their exposure time. When the drying temperature is $50{ }^{\circ} \mathrm{C}$, water losses increase regardless of the drying time. The use of high temperatures $\left(80^{\circ} \mathrm{C}, 90^{\circ} \mathrm{C}\right)$ leads to considerable weight loss on samples $(5 \mathrm{~g}, 10 \mathrm{~g}, 15 \mathrm{~g})$ which can reach $90 \%$ depending on the humidity of the product. Which seems huge since water is the major component of eggplant and preservation of mass is still a requirement. The choice of the drying time $" 80{ }^{\circ} \mathrm{C}, 90$ ${ }^{\circ} \mathrm{C} "$ makes it possible to limit the losses mentioned above, in particular the losses of vitamins. With this method, losses can be reduced. However, these cannot fully confirm the hypothesis that oven drying preserves the component levels of plant products, especially the mineral contents. According to [16], the degradation and loss of components of plant products under the effect of heat treatment with steam depends on temperature, exposure time, humidity and type of food. Since cooking brings about structural changes affecting the rheological properties of the treated product, this work shows the effect of the drying method on the firmness of the eggplant. Based on the work of [17], the loss of firmness of plant tissues is very rapid during the first minutes of drying at high temperature $\left(80^{\circ} \mathrm{C}, 90^{\circ} \mathrm{C}\right)$. The results of work show that the drying has a faster impact on the firmness presented the different curves. In this context, drying at $\left(50{ }^{\circ} \mathrm{C}, 60^{\circ} \mathrm{C}\right)$ remains more interesting if the preservation of the original integrity of the tissue structure and a certain firmness is indeed desired for small masses of samples. The load occupied by the oven and the initial water content of the products also have a significant influence and a significant impact on the loss rates: A very high load inside the oven makes it possible to modify the physicochemical characteristics and consequently the injection of the water vapor and the pulsed air flow [15], This work content to compare the experimental results according to the choice of temperature and drying time and the weight of the eggplant. The acidity of eggplants increases during drying. This acidity changes with increasing drying temperature. The highest level of acidity is recorded by temperatures of $80^{\circ} \mathrm{C}$ and $90^{\circ} \mathrm{C}$. This increase in acidity could be related to the partial fermentation of the samples, due to the drying time, and to the enzymatic activity of pectin during the initial 
phase of drying [18]. According to [19], acidity does not evaporate during drying, so dried fruit is normally more acidic than fresh fruit. All eggplant samples analyzed were judged to be acidic. There are no fixed limits for $\mathrm{pH}$ values but this parameter can be used as an indication of botanical origin [21]. The variation in the $\mathrm{pH}$ of the samples would be due to the application of the different temperatures on the eggplant samples. Ascorbic acid or vitamin $\mathrm{C}$ is an antioxidant in food [17]. It plays an important role in maintaining the intercellular material of cartilage and bones. Vitamin $\mathrm{C}$ facilitates the digestion of non-heminic iron, it is known for its anti-free radical effects (neutralization of free radicals such as superoxide and hydroxyl radicals) and is a reducer of transition metals, and as an enzyme cofactor, and is a regulator of electron transport [22]. Vitamin C stimulates the immune system and increases the amount of glycogen in the liver and muscles. [23]. The results of this study reveal the rate of loss of vitamin $\mathrm{C}$ during different drying temperatures. This decrease in vitamin $\mathrm{C}$ is linked to the heat sensitivity of the vitamins [24]. Indeed, vitamin $C$ is the most fragile of all vitamins, it is sensitive to water and heat. According to [25], the ascorbic acid content is affected by the heating of all fruits and vegetables and the increase in drying time causes a decrease in the ascorbic acid content due to the properties of vitamin $\mathrm{C}$ which is water soluble so it is easily soluble in water and then degraded by heat. Vitamin $\mathrm{C}$ losses are more pronounced with low weight samples $(5 \mathrm{~g})$ and those for all temperatures. So the loss of vitamin $\mathrm{C}$ in eggplants is linked to the weight of the different eggplant slices. According to [21], slicing and dicing vegetables increases the rate of loss of vitamin $\mathrm{C}$ before and after cooking.

\section{CONCLUSION}

This study was performed to assess the effects of oven drying on the physicochemical parameters of eggplant. The physicochemical parameters (humidity, $\mathrm{pH}$, titratable acidity and vitamin $\mathrm{C}$ ) of 5, 10 and 15g eggplant samples were analyzed. The analyzes carried out show that the transformation techniques influence each of the parameters studied. The biochemical composition of the eggplant slices revealed that drying results in the loss of water, vitamin $\mathrm{C}$ and $\mathrm{pH}$ from the eggplants during drying. However, the acidity of eggplants has shown the opposite effect, it increases during drying

\section{COMPETING INTERESTS}

Author has declared that no competing interests exist

\section{REFERENCES}

A.O.A.C. Official Methods of Analysis. 15th Edn., Association of Official Analytical Chemists, Washington DC., USA., pp: 200-210, (1990).

Barbier. Sustainable nondestructive mangrove-friendly aquaculture in Nigeria I: Ecological and environmental perspectives. Values and ecosystem services of mangroves. 93p, 1994

Board, B.W. Le contrôle de la qualité dans l'industrie du traitement des fruits et légumes. Etude FAO Alimentation et Nutrition (39), 81 p, 1987.

Bougrat, M. L'hypovitaminose C : savoir y penser à partir de quatre cas cliniques. Thèse de Doctorat d'état en médecine. Université de Nantes, (Nantes, France). 2017, 179p.

Christelle, SM., Osty, P.L. and Lardon, S. Comment analyser les transformations de l'activité productrice des agriculteurs Propositions à partir des systèmes techniques de production. Etud.Rech, Syst, Agraire Der, 31 :397-413, (1998).

Greve, C. L., MacArdle, R. N., Gohlke, J.R., Labavitch J. M. "Impact of heating on Carrot Firmness: Changes in cell wall components." J. Agric. Food Chem. 42: 2900-2906, 1994.

Hao, F., Yun, Y. and Tang, J. Microwave Drying of Food and Agricultural Materials: Basics and Heat and Mass Transfer Modeling. Review article. Food Engineer Review. 10(2):884-904, 2012.

Correia, A.F.K., Loro, A.C., Zanatta, S., Spoto, M.H.F. and Vieira, T.M.F.S. Effect of temperature, time, and material thickness on the dehydration process of tomato. International journal of food science, 15 p, 2015.

Davey, M.W., Montagu, M.V. and Inzé, D. Plant L-ascorbic acid: Chemistry, function, metabolism, bioavailability and effects of processing. Journal of the Science of Food and Agriculture, 80 (7): 825 - 860, 2000. 
Elgamouz, Le suivi de la teneur de la vitamine C dans un jus Industriel. Mémoire de Master en Chimie des Molécules Bio Actives, Facultés Sciences et Techniques, Université Sidi Mohammed Ben Abdellah, (Fès, Maroc). 54p, 2016.

Ertekin, C. and Yalidz, O. Drying of eggplant and selection of a suitable thin layer drying model. Journal of Food Engineering 63: 349-359, 2004.

Fraile, P. Détermination des caractéristiques d'une cellule de cuisson à vapeur d'eau surchauffée : application à la remise en température d'un plat cuisiné et modélisation. Thèse, Ecole Nationale supérieure des Mines de Paris,(Paris, France). 192p, 1995

Harisoamahefa, H. Etude des modalités de séchage de fruits et légumes au moyen du séchoir solaire boara; qualités nutritionnelles et microbiologiques des produits obtenus. Mémoire pour l'obtention du diplôme d'étude approfondie de sciences de la vie. Faculté des Sciences. Université d'Antananarivo, (Antananarivo, Madagascar), $113 p, 2013$.

Huang, J., Zhang, M., Adhikari, B. and Yang, Z. Effect of microwave air spouted drying arranged in two and three stages on the drying uniformity and quality of dehydrated carrot cubes. Journal of Food Engineering. 177, 80-89, 2016.

Igwemmar, N.C. and Kolawole, S.A. Effect of heating on vitamin C content of some selected vegetables. International Journal of Latest Research in Science and Technology, 2013, 2: 210-212

Lahmari, N., Azani, I. and Fahloul, D. Influence des méthodes de séchage sur la qualité des tomates séchées (variété Zahra). Materials Science. 8(2): 3-5, 2012.

Lizada C., Mango. I., Seymour G.B., Taylor J.E. and Tucker G.A. Biochemistry of fruit ripening. London, 465 p, 1993.

Ndife J., Elija I., Onwuzuruike A., Ubbor S. and Ojinnaka M. C. Impact of Blanching Pretreatment on the Quality Characteristics of Three Varieties of Oven Dried Eggplant. International Journal of Agriculture and Biological Sciences. 8 (3) 2522-6584, 2019.

Dufour, D., Larsonneur, S., Alarçon, F., Brabet, C. and Chuzel, G. Improving the bread making potential of cassava sour starch. Cali CIAT, 4: 133- 142, (1996).

Okanlawon, S.O., Ibrahim, M.H. and Oyebani, A.O. Effect of pre-drying treatment on the storage of dried tomato. Trop Sci. 42:40-41, 2002. [Google Scholar]

Rehman, Z.U., Islam, M. and Shah, W.H. Effect of microwave and conventional cooking on insoluble dietary fibre components of vegetables. Food Chemistry. 80 (2) : 237-240, 2003.

Ricardo, L.M., Bruno, A.M. and Laurindo, B.J.A. A microwave multi-flash drying process for producing crispy bananas. Journal of Food engineering. 178:1-11, 2016.

Samoticha J., Wojdyło A. and Lech K. The influence of different the drying methods on chemical composition and antioxidant activity in chokeberries. Food Science and Technology. 66p, 2016.

N’zi J., C., Kouamé N'guetta A., Fondio L. and Djidji A. Sangaré A.,. Evolution des populations de Bemisia tabaci Genn. Selon les variétés de tomate (Solanum lycopersicum L.) au Centre de la Côte d'Ivoire. Sciences \& Nature. 7 (1) 31 40, 2010.

Vanhanen, L.P., Geoffrey, P.S. and Emmertz, A. Mineral analysis of mono-floral New Zealand honey. Food Chemistry. (1): 236-240, 2011. 